Oak Ridge National Laboratory on the high purity of these samples. Assistance with wavelength calculations was given by W. Lyle, R. Cross, and R. Murphy, and the direct-current arc spectrograms were made by W. Bozman.

\section{References}

[1] D. I. Mendeléeff, J. Russ. Chem. Soc. 1, 60 (1869).

[2] H. J. G. Moseley, Phil. Mag. 26, 1024 (1913); 27, 703 (1914).

[3] W. Noddack, I. Tacke, und O. Berg, Naturwissenschaften 13, 567 (1925)

[4] W. F. Meggers, J. Research NBS 6, 1027 (1931) RP322.

[5] E. Segré, Sci. Monthly 5\%, 12 (1943).
[6] C. Perrier and E. Segré, J. Chem. Phys. 5, 712 (1937); 7, 155 (1939).

[7] C. Perrier and E. Segré, Nature 159, 24 (1947).

[8] Plutonium Project, J. Am. Chem. Soc. 68, 2411 (1946).

[9] G. W. Parker, J. Reed, and J. W. Ruch, CNL-1, Clintor National Laboratory, Contract No. W-35-058-ing-71, (Jan. 9, 1948).

[10] M. G. Inghram, Phys. Rev. 72, 1269 (1947).

[11] D. L. Timma, J. Optical Soc. Am. 39, 898 (1949).

[12] L. E. Burkhart, W. F. Peed and B. G. Saunders, Phys. Rev. 73, 347 (1948).

[13] W. F. Meggers and B. F. Scribner, Y-476, Oak Ridge Spectroscopy Symposium, Abstracts of Papers (March 24 to 25,1949 ).

[14] W. F. Meggers and B. F. Scribner, J. Opt. Soc. Am. 39, 1059 (Abstract) (1949).

Washington, August 21, 1950.

\title{
Dissociation Constants of 4-Aminobenzophenone Calcu- lated From Ultraviolet Spectra at Several Temperatures
}

\author{
By Elizabeth E. Sager and Iris J. Siewers
}

\begin{abstract}
Many of the physical-chemical properties of compounds of low solubility are difficult to determine because of the necessarily small concentrations of material. In many cases advantage may be taken of measurements of the absorption spectra if the bands occur in favorable ranges of the spectrum. The diphenyl ketones fall in this category and have been the subject of recent studies.

The ultraviolet absorption spectra of several concentrations of benzophenone, 4-aminobenzophenone, and 4, $4^{\prime}$-diaminobenzophenone have been measured and their molar absorbencies determined. The dissociation of 4-aminobenzophenone, a weak base, has been carefully studied at temperatures from $10^{\circ}$ to $40^{\circ} \mathrm{C}$ in 5-degree steps. Dissociation constants for each temperature, as well as activity coefficient terms, have been calculated. The heat of dissociation has also been determined.
\end{abstract}

\section{Introduction}

The acidic or basic properties of many slightly soluble compounds have not been determined because of experimental difficulties in applying the usual titration or electromotive-force methods to very low concentrations. Diphenylketones, such as benzophenone, 4-aminobenzophenone and 4,4'diaminobenzophenone, are practically insoluble in water and fall in this category. They are colorless in aqueous solution, but their aromatic structure suggests that their ultraviolet spectra may be used to study some of their chemical properties. Accurate spectrophotometric measurements of concentrations as low as $10^{-4}$ or $10^{-5}$ molar can now be made at many temperatures. The observed changes in spectral absorbancy with changes in hydrogen-ion concentrations can be used to calculate dissociation constants and other related thermodynamic quantities.

The molar absorbancies of the molecular and ionic states of benzophenone, 4-aminobenzophenone, and $4,4^{\prime}$-diaminobenzophenone were first determined and compared. The parent compound, benzophenone, has no group to ionize, and its spectral curves are identical whether the material is in aqueous, acid, or basic medium. 4-Aminobenzophenone is a weak base and does not dissociate appreciably in aqueous solution, as demonstrated by identical curves of the free base in water and in various concentrations of alkali. Moderately strong acid is required to effect complete dissociation, as evidenced by the entirely different absorbancy curve in the near ultraviolet. $4,4^{\prime}$-Diaminobenzophenone has two groups whose dissociation ranges overlap, and extensive experimental data will be required to determine the constants.

A comprehensive study of the dissociation of 4aminobenzophenone has been made at several temperatures, and the constants at $10^{\circ}, 15^{\circ}, 20^{\circ}, 25^{\circ}$, $30^{\circ}, 35^{\circ}$, and $40^{\circ} \mathrm{C}$ have been calculated and are reported in this paper. Hydrochloric acid was used to control the hydrogen-ion concentrations at various stages during the dissociation. The contribution of the $10^{-5}-M$ base to ionic strengths of $10^{-3}$ and $10^{-2}-M$ hydrochloric acid is so small that it can be neglectedthus the hydrogen-ion concentration may be taken as that of the known amount of hydrochloric acid.

The limiting spectral absorbancy curves of the free base and of the ionized compound do not change with change in temperature in the range studied, which is very fortunate. At a given temperature, then, all changes in absorbancy for one dissociation series may be attributed solely to the dissociation reaction. Another favorable factor is that 4-aminobenzophenone dissociates over a $\mathrm{pH}$ range of 1 to 3 , where the temperature has little influence upon $\mathrm{pH}$ values. 
For instance, the $\mathrm{pH}$ of $0.005-M$ hydrochloric acid on a comparative scale at $10^{\circ} \mathrm{C}$ is 2.332 , and at $40^{\circ} \mathrm{C}$ it is 2.334 , a negligible difference.

The concentration constants for the dissociation are determined in the following manner. The degree of dissociation and resulting ratios of free base to ions are calculated from the absorbancy data. The hydrogen-ion concentrations are known from the amounts of hydrochloric acid in the solutions. The products of the hydrogen-ion concentration and the ratios of free base to ions give the concentration constants, $K_{c}$. By plotting $-\log _{10} K_{c}$ as a function of ionic strength, practically straight lines with slight slopes are obtained that may be extrapolated to infinite dilution for estimated $-\log _{10} K_{a}$, or $\mathrm{p} K_{a}$ values for each temperature. The activity coefficient terms for the weak base can also be expressed as a function of jonic strength. Employing the usual thermodynamic equations, the heat of dissociation, $\Delta H$, may also be calculated.

\section{Experimental Procedure}

\section{Materials}

Benzophenone was obtained from Eastman Kodak Co., and 4-aminobenzophenone and 4,4'-diaminobenzophenone were obtained from Dow Chemical Co. The benzophenone, a white crystalline compound, melted at $48.6^{\circ}$ to $49.2^{\circ} \mathrm{C}$. The 4 -aminobenzophenone, a pale yellow crystalline compound, melted at $123.0^{\circ}$ to $123.4^{\circ} \mathrm{C}$. The $4,4^{\prime}$-diaminobenzophenone, a yellow crystalline material, melted at $244.1^{\circ}$ to $244.4^{\circ} \mathrm{C}$.

Hydrochloric acid of reagent grade was used to make stock solutions, $10^{-1}-M$, for the majority of the dilutions. Stronger acid was required in some cases for determining limiting absorbancy curves. Sodium hydroxide, approximately $10^{-1}-M$, was prepared free from carbonate, from which weaker concentrations of alkali were made. Conductivity water was used to dissolve the compounds under investigation and in making all stock solutions and subsequent dilutions.

\section{Equipment}

A model DU Beckman spectrophotometer was modified with a constant-temperature cell compartment of our own design. ${ }^{1}$ The cell compartment is essentially a metal-box air bath, jacketed on all sides, top, and bottom, through which water circulates from a constant-temperature bath. ${ }^{2}$ It was designed especially to accommodate large cylindrical absorption cells of $38-\mathrm{mm}$ inside diameter, described in previous publications $[1,2,3] .^{3}$ The cells are Pyrex cylinders of $1-, 2-$, and 5-cm length with openings for filling and emptying and are fitted with removable end-plates of crystalline quartz.

\footnotetext{
1 The constant-temperature cell compartment was designed with the aid of W. S. Hertstein, draftsman, of the Instrument Shop of this Bureau, who made many helpful suggestions. I. W. Lund, also of the Instrument Shop, constructed the metal box, metal holders, and other parts necessary to modify the instrument. ${ }_{2}$ A 16-gallon constant-temperature bath of American Instrument Co. design was used.

${ }_{3}$ Figures in brackets indicate the literature references at the end of this paper.
}

The cell assemblies are held together with metal containers and screw caps, using Bakelite and rubber gaskets. All cells, end-plates, and metal parts were made at this Bureau. One complete cell assembly measures about $44 \mathrm{~mm}$ in over-all diameter and $60 \mathrm{~mm}$ in over-all length. To allow passage of the radiant energy from the exit slit through the cells and solutions to the photocell compartment, two round openings about $22 \mathrm{~mm}$ in diameter were made in opposite sides of the waterjacketed box. Only two cells can be accommodated. Each cell is held in a metal cradle attached to a sliding rod, by which mechanism they can be placed alternately in the path of radiant energy. The metal housing with the source of energy was moved back about 1 in. so that it is not in contact with the metal walls of the cell compartment.

\section{Temperature Control}

The water bath was maintained at the desired temperature, between $10^{\circ}$ and $40^{\circ} \mathrm{C}$ within \pm 0.1 deg C. Water, initially at the bath temperature, circulates through four lengths of hose attached to the two inlets and outlets of the cell compartment and cover in the room at $25^{\circ} \mathrm{C}$. Consequently, the temperature within the cell compartment is not exactly that of the water bath when it is above or below $25^{\circ} \mathrm{C}$. The temperatures reported are readings taken from a thermometer with only the mercury-bulb tip inserted in a rubber stopper in the removable top. Care was taken not to allow more than the tip of the thermometer inside the box during spectrophotometric observations, so that extraneous light could not be introduced. In order to shorten the time for the solutions in the cells to attain the desired equilibrium temperature, several volumetric flasks containing the solutions for a series were placed in wire baskets that were suspended in the water bath. The cells were emptied, washed, and filled in the room at $25^{\circ} \mathrm{C}$, and $30 \mathrm{~min}$ or more was allowed for the solutions in the cells to attain constant temperature.

\section{Spectrophotometric Observations}

The transmittancy readings were made at wavelength settings $2 \mathrm{~m} \mu$ apart over the ultraviolet range of 210 to $400 \mathrm{~m} \mu$, inclusive. Usually the maxima and minima of the bands were first read, then the series of observations recorded at even wavelengths from 210 through $400 \mathrm{~m} \mu$. A check of the values at selected wavelengths was then made in reverse order. In this manner any change or trend in the transmittancy readings could usually be detected. A period of 30 to 40 min was required to make 160 or more observations. The reproducibility of transmittancy observations was usually within \pm 0.1 percent.

\section{5. $\mathrm{pH}$ Measurements}

In this study $\mathrm{pH}$ measurements were used only as a check on the prepared solutions, as hydrogen-ion 
concentrations were the known hydrochloric acid concentrations. All solutions were measured with commercial glass-electrode assemblies at $25^{\circ} \mathrm{C}$. A Cambridge $\mathrm{pH}$ meter was used for most of the measurements, but Beckman and Leeds and Northrup instruments were also employed.

\section{Molar Absorbancies of Benzophenone, 4-Aminobenzophenone, 4,4'-Diaminoben- zophenone}

Spectrophotometric measurements of various concentrations of benzophenone, 4-aminobenzophenone, and 4,4'-diaminobenzophenone were made using 1-, $2-$, and 5-cm absorption cells. This was done first to check the validity of the Beer-Lambert law of absorption, which states that at any given wavelength or wave number

$$
a_{M}=A_{s} / b M
$$

in which $a_{M}$ is the molar absorbancy index, $A_{s}$ is the specific absorbancy of the sample ( $-\log _{10}$ transmittancy), $b$ is the depth of solution in centimeters through which the radiant energy passes, and $M$ is the molar concentration of the absorbing compound. One may vary the concentration of the compound or change the depth of solution by using different cell lengths, and if the same curves of molar absorbancy index are obtained over the spectral range of observed wavelengths, then $A_{s} / b M$ is a constant and there is conformation to the absorption law.

The three curves in figure 1 represent the molecular, or undissociated, states of benzophenone, $\mathrm{R}$; 4-aminobenzophenone, $\mathrm{RNH}_{2} ;$ and 4,4'-diaminobenzophenone, $\mathrm{R}\left(\mathrm{NH}_{2}\right)_{2}$ in aqueous or alkaline solution at $25^{\circ} \mathrm{C}$. Molar absorbancy index is plotted as a function of wave number with the corresponding wavelengths shown at the top of the figure. Benzophenone has a maximum molar absorbancy index of 17,300 at $38,760 \mathrm{~cm}^{-1}(258 \mathrm{m \mu})$. 4-Aminobenzophenone shows a maximum absorbancy index of 15,900 at $30,100 \mathrm{~cm}^{-1}(332 \mathrm{m \mu})$ with a secondary band of 11,900 index at $40,800 \mathrm{~cm}^{-1}(245 \mathrm{~m} \mu)$. 4,4'-Diaminobenzophenone shows greatly increased absorbancy with a main band of 23,500 index at $29,600 \mathrm{~cm}^{-1}$ $(338 \mathrm{~m} \mu)$ and a secondary band of 13,000 index at $42,400 \mathrm{~cm}^{-1}(236 \mathrm{~m} \mu)$.

The same curve is obtained for benzophenone whether in aqueous solution, or acid or alkaline medium, as it has no group to dissociate. Also the curves are the same for the two amino compounds whether in aqueous solution or in alkali, demonstrating the fact that in water they do not dissociate appreciably but remain as free bases in the molecular state. To avoid confusion, the curves for the ionic states or the dissociated states of the aminobenzophenones are not given in this graph. However, they are similar to the curve for benzophenone with slightly increased absorbancy and slight shift of their bands of maximum absorbancy to higher wave numbers.

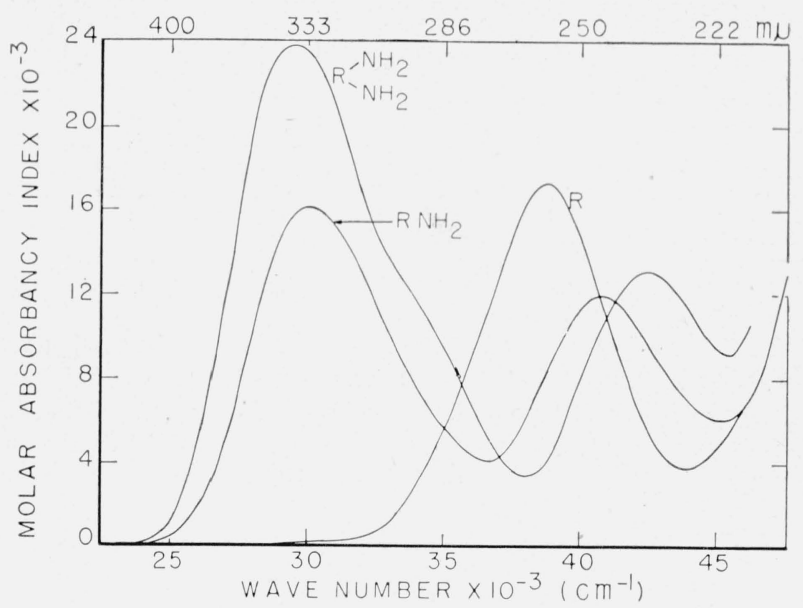

FiguRE 1. Comparison of the ultraviolet absorption spectra of benzophenone, $\mathrm{R}$, 4-aminobenzophenone, $\mathrm{RNH}_{2}$, and 4, $4^{\prime}$ diaminobenzophenone, $\mathrm{R}\left(\mathrm{NH}_{2}\right)_{2}$.

\section{Calculation of Dissociation Constants of 4-Aminobenzophenone from Spectral Data}

\section{Spectral Absorbancy Data}

A typical set of transmittancy measurements over the ultraviolet range of the spectrum for a dissociation series is shown in figure 2. They are of 4aminobenzophenone, $5 \times 10^{-5}-M$ in $1-\mathrm{cm}$ cells at various hydrogen-ion concentrations at $25^{\circ} \mathrm{C}$ given in table 1 . The observed transmittancies in percentage are plotted as a function of wavelength. The free base, or undissociated 4-aminobenzophenone, is represented by curve 17 . The completely dissociated compound is plotted as curve 1 , and the 15 intermediate curves represent the partially dissociated base at various stages at known hydrogenion concentrations. It is readily seen that the two limiting curves, 1 and 17, intersect each other at three points, giving at least two well-defined isosbestic points at $242 \mathrm{~m} \mu$ and at $283.5 \mathrm{~m} \mu$, which hold

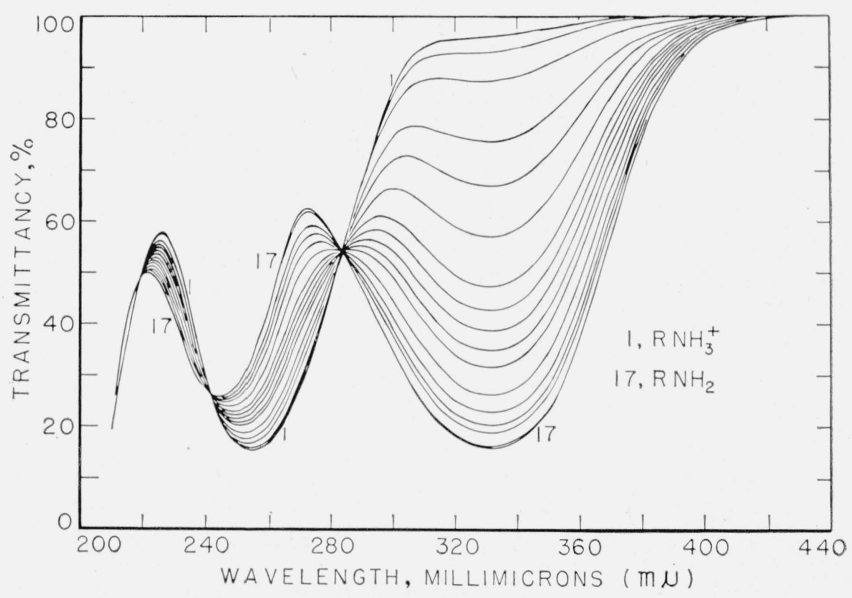

FIgURE 2. Transmittancy curves of 4-aminobenzophenone as the free base (curve 17), the dissociated compound (curve 1), and 15 intermediate stages during the dissociation. 


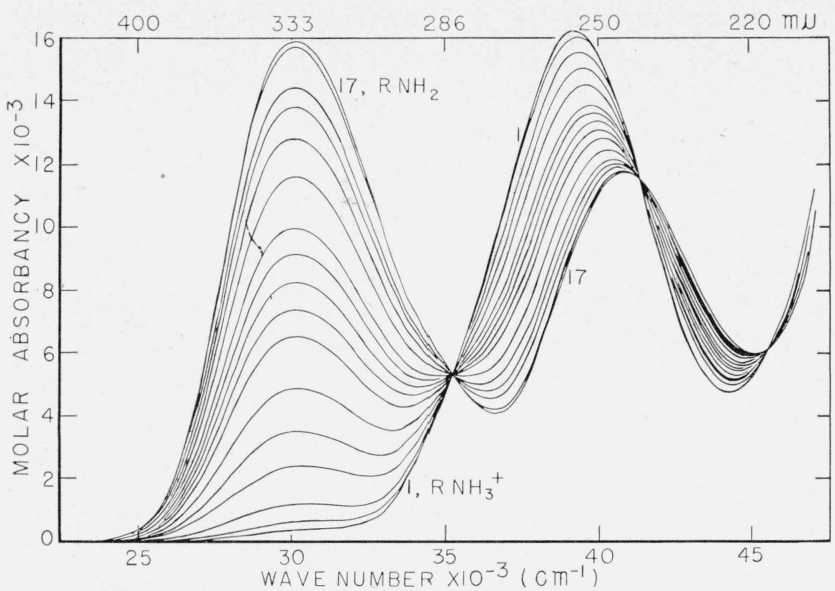

Figure 3. Molar absorbancy curves of 4-aminobenzophenone as the free base (curve 17), the dissociated compound (curve 1), and 15 intermediate stages during the dissociation.

for the entire series. The constancy of these points of equal transmittancy or absorbancy is very important in that it indicates purity and stability of the compound, and also that only one reaction is taking place, in this case, that of dissociation.

The same data are presented in figure 3 , with molar absorbancy index $\times 10^{-3}$ plotted as a function of wave number with the corresponding wavelengths given at the top of the figure. Curves 1 and 17 represent the dissociated and free base, respectively. As the concentration of hydrogen-ion is increased the broad band of the free base at $30,100 \mathrm{~cm}^{-1}$ decreases, until upon complete dissociation there is almost negligible absorbancy. One might assume that sufficient acid would suppress this band completely, but high concentrations of acid were found to cause other chemical changes, indicated by some changes in absorbancy at higher wave numbers and a slight shift in the isosbestic points. The limiting curve for the dissociated state was very carefully determined using $0.3-, 0.4-, 0.5-, 0.6-, 0.81-, 1.0-$, and $2.0-M$ hydrochloric acid. At $0.6-M$ acid, the absorbancy at wave number 30,100 was lowest and there was no evidence of displacement of the isosbestic points.

The secondary band of the free base, curve 17, with maximum absorbancy at $40,800 \mathrm{~cm}^{-1}$, increases with increase in hydrogen-ion concentration and shifts toward the lower wave numbers as it approaches the absorbancy of the dissociated compound, curve 1. Practically all measurements in this portion of the ultraviolet range are on steep sides of the bands, as evidenced in figure 2, and do not have the accuracy of the measurements at lower wave numbers.

\section{Method of Calculation of Concentration Constants}

The acidic dissociation of the ammonium ion of 4-aminobenzophenone may be expressed as follows

$$
\mathrm{RNH}_{3}^{+} \rightleftarrows \mathrm{RNH}_{2}+\mathrm{H}^{+} \text {. }
$$

The concentration constant, $K_{c}$, may first be calcu- lated, neglecting for the present the activity coefficient terms for the free base and ions, according to the equation

$$
K_{c}=\frac{\left[\mathrm{RNH}_{2}\right]\left[\mathrm{H}^{+}\right]}{\left[\mathrm{RNH}_{3}^{+}\right]}
$$

in which $\left[\mathrm{RNH}_{2}\right],\left[\mathrm{H}^{+}\right]$, and $\left[\mathrm{RNH}_{3}^{+}\right]$are the concentrations of free base, hydrogen-ion, and dissociated compound, respectively. A familiar way of expressing this relation is

$$
K_{c}=\frac{(1-\alpha)\left[\mathrm{H}^{+}\right]}{\alpha},
$$

in which $\alpha$ represents the degree of dissociation into ions and $1-\alpha$ the remaining free base.

The amounts of either base or ions are proportional to their molar absorbancy indices as in eq 1 . For brevity let $a_{M}(\mathrm{R}), a_{M}\left(\mathrm{R}^{+}\right)$, and $a_{M}{ }^{\prime}$, represent, respectively, the molar absorbancy index at any wavelength of the free base, the ions, and mixtures of the two during the dissociation.

As differences in absorbancies are used to calculate $\alpha$ or the amount of $\mathrm{RNH}_{3}^{+}$formed at any stage in the dissociation, a graphical illustration of the differences is given in figure 4 . The total change in absorbancy from free base to ions is given as the outer curve labeled $a_{M}\left(\mathrm{RNH}_{2}\right)-a_{M}\left(\mathrm{RNH}_{3}^{+}\right)$. The differences for intermediate stages are represented by the 12 remaining curves, one of which is labeled $a_{M}\left(\mathrm{RNH}_{2}\right)-a_{M}^{\prime}$. One can readily see that the differences are positive for the large band nearest the visible, zero for the isosbestic point at $283 \mathrm{~m} \mu$, all negative between 283 and $242 \mathrm{~m} \mu$, and positive again for the data at the lower wavelengths. The degree of dissociation, or $\alpha$, is calculated according to eq 4 , and the amount of free base remaining, $1-\alpha$, according to eq 5 as follows:

$$
\begin{aligned}
\alpha & =\frac{a_{M}(\mathrm{R})-a_{M}{ }^{\prime}}{a_{M}(\mathrm{R})-a_{M}\left(\mathrm{R}^{+}\right)}, \\
1-\alpha & =\frac{a_{M}{ }^{\prime}-a_{M}\left(\mathrm{R}^{+}\right)}{a_{M}(\mathrm{R})-a_{M}\left(\mathrm{R}^{+}\right)},
\end{aligned}
$$

Theoretically, the values of $\alpha$ should be the same across the spectral range regardless of wavelength selected. It is obvious that the best estimates will be obtained where the differences in absorbancies are greatest. Data too near the isosbestic points are worthless in such calculations. It is wise to examine the $\alpha$ values across reasonable wavelength ranges in more than one band, to detect a possible trend. Such trends have often been noted [1, 2], particularly where impurities may be involved, or where another reaction can conceivably take place simultaneously. Dissociation constants calculated from absorbancies at one or two wavelengths are not necessarily reliable. In this case the authors selected the wavelength range of 314 to $350 \mathrm{~m} \mu$, inclusive, to calculate an average $\alpha$ from 19 wavelengths. A comparison was made with values calculated from 256 to 264 $\mathrm{m} \mu$ in which greater variations occurred because 
observations were made on steep slopes of bands, and there was satisfactory agreement.

The ratios of free base to ions may be calculated directly by combining eq 4 and 5 , thus

$$
\frac{1-\alpha}{\alpha}=\frac{a_{M^{\prime}}-a_{M}\left(\mathrm{R}^{+}\right)}{a_{M}(\mathrm{R})-a_{M^{\prime}}}
$$

This ratio multiplied by the hydrogen-ion concentration gives the concentration constant $K_{c}$, as in eq 2 or 3 . $\mathrm{p} K_{c}$, the negative of the common logarithm of $K_{c}$, can then be calculated.

\section{Presentation of Data}

Typical absorbancy data and calculated values for the dissociation of 4-aminobenzophenone at $25^{\circ} \mathrm{C}$ are given in table 1 . Two series show reproducibility of results from two different runs, using freshly prepared solutions throughout. The molar concentration of hydrochloric acid is given in column 1. Molar absorbancy index at $332 \mathrm{~m} \mu$ is listed in column 2. Column 3 shows $\alpha$ calculated from absorbancies at one wavelength $(332 \mathrm{~m} \mu)$, and column 4 gives an average $\alpha$ calculated from absorbancies at 19 wavelengths from 314 to $350 \mathrm{~m} \mu$, inclusive. Inasmuch as the transmittancy observations are subject to error in the third figure, this error is carried in the subsequent calculations. An

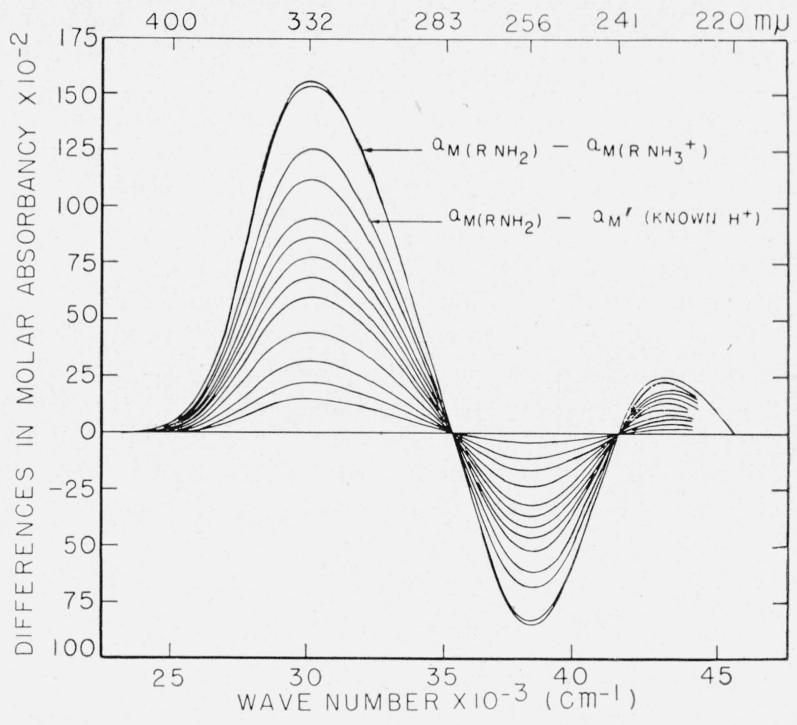

FiguRE 4. Differences in absorbancy of undissociated 4-aminobenzophenone and the partially and completely dissociated compound.

average $\alpha$, however, should minimize the error. Values of $\alpha$ below 0.1 and above 0.9 yield unusually large or small ratios of free base to ions and were not included in the calculations of the constants.

TABLE 1. Dissociation of 4 -aminobenzophenone at $25^{\circ} \mathrm{C}$.

\begin{tabular}{|c|c|c|c|c|c|c|}
\hline $\begin{array}{c}\text { Molar con- } \\
\text { centration } \\
\text { of } \mathrm{HCl} \\
{\left[\mathrm{H}^{+}\right]}\end{array}$ & $\begin{array}{c}\text { Molar ab- } \\
\text { sorbancy } \\
\text { index, } \lambda 332 \\
a_{M}\end{array}$ & $\begin{array}{c}\text { Amount dis- } \\
\text { sociated into } \\
\text { ions, } \lambda 332, \\
1 \text { wavelength } \\
\alpha\end{array}$ & $\begin{array}{l}\text { Amount dis- } \\
\text { sociated into } \\
\text { ions, } \lambda 314 \text { to } \\
350, \text { incl. } \\
\text { Average of } \\
19 \lambda\end{array}$ & $\begin{array}{l}\text { Ratio of free } \\
\text { base to ions, } \\
\\
(1-\alpha) / \alpha\end{array}$ & $\begin{array}{l}\text { Concentra- } \\
\text { tion constant, } \\
K_{c} \times 10^{3} \\
{\left[\mathrm{H}^{+}\right] \frac{(1-\alpha)}{\alpha}}\end{array}$ & $\begin{array}{c}-\log _{10} K_{c}, \\
\mathrm{p} K_{c}\end{array}$ \\
\hline \multicolumn{7}{|c|}{ SERIES A } \\
\hline $\begin{array}{r}0.0000 \\
.0001 \\
.0065 \\
.0010 \\
.0016\end{array}$ & $\begin{array}{l}15,900 \\
15,700 \\
14,500 \\
13,800 \\
12,800\end{array}$ & $\begin{array}{r}0.000 \\
.013 \\
.090 \\
.135 \\
.199\end{array}$ & $\begin{array}{r}0.000 \\
.014 \\
.092 \\
.133 \\
.196\end{array}$ & $\begin{array}{l}6.518 \\
4.102\end{array}$ & $\begin{array}{l}6.518 \\
6.563\end{array}$ & $\begin{array}{l}2.186 \\
2.183\end{array}$ \\
\hline $\begin{array}{l}.0026 \\
.0041 \\
.0052 \\
.0065 \\
.0102\end{array}$ & $\begin{array}{r}11,600 \\
9,980 \\
9,150 \\
8,250 \\
6,500\end{array}$ & $\begin{array}{l}.276 \\
.381 \\
.434 \\
.492 \\
.604\end{array}$ & $\begin{array}{l}.277 \\
.380 \\
.433 \\
.492 \\
.606\end{array}$ & $\begin{array}{l}\text { 2. } 610 \\
\text { 1. } 632 \\
\text { 1. } 309 \\
\text { 1. } 032 \\
0.828\end{array}$ & $\begin{array}{l}6.786 \\
6.691 \\
6.807 \\
6.708 \\
6,707\end{array}$ & $\begin{array}{l}2.168 \\
2.175 \\
2.167 \\
2.174 \\
2.174\end{array}$ \\
\hline $\begin{array}{l}.0161 \\
.0256 \\
.0405 \\
.1020 \\
.6440\end{array}$ & $\begin{array}{l}4,870 \\
3,470 \\
2,410 \\
1,180 \\
350\end{array}$ & $\begin{array}{r}.709 \\
.799 \\
.868 \\
.947 \\
1,000\end{array}$ & $\begin{array}{r}.711 \\
.799 \\
.868 \\
.948 \\
1.000\end{array}$ & $\begin{array}{c}.406 \\
.252 \\
.152 \\
\\
\end{array}$ & $\begin{array}{l}6.537 \\
6.451 \\
6.156 \\
\end{array}$ & $\begin{array}{l}2.185 \\
2.190 \\
2.208 \\
- \\
\end{array}$ \\
\hline \multicolumn{7}{|c|}{ SERIES B } \\
\hline $\begin{array}{r}0.0000 \\
.0016 \\
.0041 \\
.0051 \\
.0064\end{array}$ & $\begin{array}{r}15,900 \\
12,800 \\
10,000 \\
9,150 \\
8,270\end{array}$ & $\begin{array}{r}0.000 \\
.199 \\
.379 \\
.434 \\
.491\end{array}$ & $\begin{array}{r}0.000 \\
.195 \\
.378 \\
.434 \\
.491\end{array}$ & $\begin{array}{l}4.128 \\
1.646 \\
1.304 \\
1.037\end{array}$ & $\begin{array}{l}6.605 \\
6.749 \\
6.650 \\
6.637\end{array}$ & $\begin{array}{l}2.180 \\
2.171 \\
2.177 \\
2.178\end{array}$ \\
\hline $\begin{array}{l}.0081 \\
.0102 \\
.0130 \\
.0160 \\
.0200\end{array}$ & $\begin{array}{l}7,370 \\
6,500 \\
5,550 \\
4,870 \\
4,150\end{array}$ & $\begin{array}{l}.549 \\
.604 \\
.666 \\
.709 \\
.756\end{array}$ & $\begin{array}{r}.547 \\
.606 \\
.665 \\
.709 \\
.756\end{array}$ & $\begin{array}{l}.828 \\
.650 \\
.504 \\
.410 \\
.323\end{array}$ & $\begin{array}{l}6.707 \\
6.630 \\
6.552 \\
6.560 \\
6.460\end{array}$ & $\begin{array}{l}2.173 \\
2.178 \\
2.183 \\
2.183 \\
2.190\end{array}$ \\
\hline $\begin{array}{l}.0256 \\
.1020 \\
.6440\end{array}$ & $\begin{array}{r}3,470 \\
1,160 \\
350\end{array}$ & $\begin{array}{r}.799 \\
.948 \\
1.000\end{array}$ & $\begin{array}{r}.800 \\
.949 \\
1.000\end{array}$ & .250 & $\begin{array}{c}6.400 \\
\end{array}$ & $\begin{array}{c}2.193 \\
\end{array}$ \\
\hline
\end{tabular}


The concentration constant, $K_{c} \times 10^{3}$, is given in column 6 , and $-\log _{10} K_{c}$, or $\mathrm{p} K_{c}$, in column 7 . The increase in $\mathrm{p} K_{c}$ with increase in ionic strength is slight, but nevertheless there is a trend. The arithmetic mean of the values of $\mathrm{p} K_{c}$ for each series is 2.18, corresponding to 0.0066 moles/liter for $K_{c}$.

A summary of calculations from spectrophotometric data that was taken of the dissociation of 4aminobenzophenone at $10^{\circ}, 15^{\circ}, 20^{\circ}, 30^{\circ}, 35^{\circ}$, and $40^{\circ} \mathrm{C}$ is given in table 2. Each series of solutions for the dissociation at one temperature was completed before changing the temperature of the water bath for the next series. Practically the same amounts of bydrochloric acid were used for each series to facilitate direct comparison of the amount of free base dissociated into ions at a particular hydrogen-ion concentration at different temperatures. The spectrophotometric observations were made as usual over the ultraviolet spectral range of 210 to $400 \mathrm{~m} \mu$, to assure accuracy of data and adherence to isosbestic points, but the degree of dissociation is the average calculated from the 19 wavelengths between 314 and $350 \mathrm{~m} \mu$. It was feared that erratic results might be obtained from the measurements at $10^{\circ} \mathrm{C}$, as a slight film formed on the outer faces of the quartz end-plates as they were removed from the cell compartment at $10^{\circ}$ to the room at $25^{\circ} \mathrm{C}$ for filling and emptying. However, the results do not seem to be out of line. At $15^{\circ} \mathrm{C}$ the film was not visible to the naked eye.

TABLE 2. Dissociation of 4 -aminobenzophenone at $10^{\circ}, 15^{\circ}, 20^{\circ}, 30^{\circ}, 35^{\circ}$, and $40^{\circ} \mathrm{C}$

\begin{tabular}{|c|c|c|c|c|c|c|c|c|c|}
\hline \multirow{2}{*}{$\begin{array}{c}\text { Molar con- } \\
\text { centration } \\
\text { of } \mathrm{HCl} \\
{\left[\mathrm{H}^{+}\right]}\end{array}$} & $\begin{array}{c}\text { Degree of } \\
\text { dissociation, } \\
\alpha\end{array}$ & $K_{\circ} \times 10^{3}$ & $-\underset{\mathrm{p} K_{c}}{-\log _{10}} K_{c}$ & $\begin{array}{c}\text { Degree of } \\
\text { dissociation, } \\
\alpha\end{array}$ & $K_{\mathrm{e}} \times 10^{3}$ & $-\underset{\mathrm{p} K_{c}}{-\log _{10} K_{c}}$ & $\begin{array}{l}\text { Degree of } \\
\text { dissocia- } \\
\text { tion, } \alpha\end{array}$ & $K_{c} \times 10^{3}$ & $-\log _{10} K_{c}$ \\
\hline & \multicolumn{3}{|c|}{$10^{\circ} \mathrm{C}$} & \multicolumn{3}{|c|}{$15^{\circ} \mathrm{C}$} & \multicolumn{3}{|c|}{$20^{\circ} \mathrm{C}$} \\
\hline $\begin{array}{r}0.0000 \\
.0016 \\
.0041 \\
.0051 \\
.0064\end{array}$ & $\begin{array}{r}0.000 \\
.271 \\
.482 \\
.537 \\
.601\end{array}$ & $\begin{array}{l}\text { 4. } 304 \\
\text { 4. } 407 \\
\text { 4. } 397 \\
4.250\end{array}$ & $\begin{array}{l}2.366 \\
2.356 \\
2.357 \\
2.371\end{array}$ & $\begin{array}{r}0.000 \\
.240 \\
.440 \\
.502 \\
.558\end{array}$ & $\begin{array}{l}5.067 \\
5.219 \\
5.059 \\
5.069\end{array}$ & $\begin{array}{l}\text { 2. } 295 \\
\text { 2. } 282 \\
\text { 2. } 296 \\
\text { 2. } 295\end{array}$ & $\begin{array}{r}\text { 0. } .000 \\
.216 \\
.413 \\
.468 \\
.534\end{array}$ & $\begin{array}{l}5.808 \\
5.826 \\
5.799 \\
5.587\end{array}$ & $\begin{array}{l}\text { 2. } 236 \\
\text { 2. } 234 \\
\text { 2. } 237 \\
\text { 2. } 252\end{array}$ \\
\hline $\begin{array}{l}.0081 \\
.0102 \\
.0130 \\
.0160 \\
.0200\end{array}$ & $\begin{array}{l}.653 \\
.707 \\
.753 \\
.794 \\
.828\end{array}$ & $\begin{array}{l}\text { 4. } 301 \\
4.223 \\
4.264 \\
4.144 \\
4.160\end{array}$ & $\begin{array}{l}2.366 \\
2.374 \\
2.370 \\
2.382 \\
2.381\end{array}$ & $\begin{array}{l}.613 \\
.670 \\
.721 \\
.763 \\
.802\end{array}$ & $\begin{array}{l}5.119 \\
5.018 \\
5.031 \\
4.976 \\
4.940\end{array}$ & $\begin{array}{l}\text { 2. } 292 \\
\text { 2. } 299 \\
\text { 2. } 298 \\
\text { 2. } 303 \\
\text { 2. } 204\end{array}$ & $\begin{array}{l}.588 \\
.643 \\
.699 \\
.741 \\
.784\end{array}$ & $\begin{array}{l}5.678 \\
5.661 \\
5.603 \\
5.600 \\
5,520\end{array}$ & $\begin{array}{l}2.246 \\
2.247 \\
2.251 \\
2.252 \\
2.258\end{array}$ \\
\hline \multirow[t]{2}{*}{$\begin{array}{l}.0256 \\
.1020 \\
.6440\end{array}$} & $\begin{array}{r}.864 \\
.969 \\
1.000\end{array}$ & $\begin{array}{r}4.019 \\
-\end{array}$ & $\begin{array}{c}2.396 \\
-\end{array}$ & $\begin{array}{r}.840 \\
.961 \\
1.000\end{array}$ & $\begin{array}{c}4.864 \\
-\end{array}$ & $\begin{array}{c}2.313 \\
-\end{array}$ & $\begin{array}{r}.826 \\
.960 \\
1.000\end{array}$ & $\begin{array}{c}5.402 \\
-\end{array}$ & $\begin{array}{c}2.267 \\
-\end{array}$ \\
\hline & \multicolumn{3}{|c|}{$30^{\circ} \mathrm{C}$} & \multicolumn{3}{|c|}{$35^{\circ} \mathrm{C}$} & \multicolumn{3}{|c|}{$40^{\circ} \mathrm{C}$} \\
\hline $\begin{array}{r}0.0000 \\
.0016 \\
.0041 \\
.0051 \\
.0064\end{array}$ & $\begin{array}{l}0.000 \\
.175 \\
.348 \\
.404 \\
.458\end{array}$ & $\begin{array}{l}7.542 \\
7.683 \\
7.522 \\
7.571\end{array}$ & $\begin{array}{l}2.122 \\
2.114 \\
2.123 \\
2.121\end{array}$ & $\begin{array}{r}0.000 \\
.159 \\
.318 \\
.371 \\
.426\end{array}$ & $\begin{array}{l}8.462 \\
8.794 \\
8.644 \\
8.621\end{array}$ & $\begin{array}{l}\text { 2. } 072 \\
2.055 \\
2.063 \\
2.064\end{array}$ & $\begin{array}{r}0.000 \\
.145 \\
.295 \\
.350 \\
.405\end{array}$ & $\begin{array}{l}9.434 \\
9.799 \\
9.471 \\
9.402\end{array}$ & $\begin{array}{l}2.025 \\
2.008 \\
2.023 \\
2.026\end{array}$ \\
\hline $\begin{array}{l}.0081 \\
.0102 \\
.0130 \\
.0160 \\
.0200\end{array}$ & $\begin{array}{l}.521 \\
.578 \\
.637 \\
.686 \\
.733\end{array}$ & $\begin{array}{l}\text { 7. } 444 \\
7.446 \\
7.410 \\
7.328 \\
7.280\end{array}$ & $\begin{array}{l}2.128 \\
2.128 \\
2.130 \\
2.135 \\
2.137\end{array}$ & $\begin{array}{l}.488 \\
.545 \\
.603 \\
.654 \\
.702\end{array}$ & $\begin{array}{l}8.497 \\
8.517 \\
8.554 \\
8.464 \\
8.48 \mathrm{C}\end{array}$ & $\begin{array}{l}\text { 2. } 070 \\
\text { 2. } 069 \\
\text { 2. } 067 \\
\text { 2. } 072 \\
\text { 2. } 072\end{array}$ & $\begin{array}{l}.464 \\
.520 \\
.581 \\
.633 \\
.683\end{array}$ & $\begin{array}{l}\text { 9. } 356 \\
9.415 \\
9.373 \\
9.280 \\
9.280\end{array}$ & $\begin{array}{l}2.029 \\
2.026 \\
2.028 \\
2.032 \\
2.032\end{array}$ \\
\hline $\begin{array}{l}.0256 \\
.1020 \\
.6440\end{array}$ & $\begin{array}{r}.784 \\
.945 \\
1.000\end{array}$ & $\begin{array}{r}7.066 \\
-\end{array}$ & $\begin{array}{c}2.151 \\
-\end{array}$ & $\begin{array}{r}.756 \\
.930 \\
1.000\end{array}$ & $\begin{array}{c}8.269 \\
-2\end{array}$ & $\begin{array}{c}2.082 \\
-\end{array}$ & $\begin{array}{r}.738 \\
.931 \\
1.020\end{array}$ & $\begin{array}{c}9.088 \\
-0\end{array}$ & $\begin{array}{c}2.041 \\
-\end{array}$ \\
\hline
\end{tabular}

It is readily seen from the table that for any given hydrogen-ion concentration the degree of dissociation decreases with increase in temperature. The concentration constant thereby increases, and $\mathrm{p} K_{c}$ correspondingly decreases.

Of interest is the magnitude of error that any variation in temperature may have upon the absorbancy of a given solution. As the limiting curves, all free base or all ions, were found to be substantially unchanged over the temperature range studied, any change in absorbancy can be attributed solely to the change in constant of the dissociation reaction with change in temperature. A solution of 4-aminobenzophenone in 0.0064- $M$ hydrochloric acid, which at $25^{\circ} \mathrm{C}$ is practically half base and half ions, was placed in the cells, and the temperature of the bath was changed in the following manner. An equilibrium temperature of $25^{\circ} \mathrm{C}$ was first attained, and observations were made at $2-\mathrm{m} \mu$ wavelength settings from 314 to $350 \mathrm{~m} \mu$, inclusive. The bath was then changed to give equilibrium temperatures in 5-deg steps, first up to $40^{\circ} \mathrm{C}$, then in reverse order down to $10^{\circ} \mathrm{C}$, and again up to $25^{\circ} \mathrm{C}$ as a check. The cells were not removed from the cell compartment, and about 3 days was required for the experiment. The changes in absorbancy were determined and the stability of the solution also proved. The results are shown in figure 5, in which specific absorbancy of the solution is plotted as a function of wavelength. In this particular case there is roughly an 8-percent increase in absorbancy with a 5-deg increase in temperature. It is evident that for accurate results close temperature control is necessary for all intermediate stages in the dissociation. 


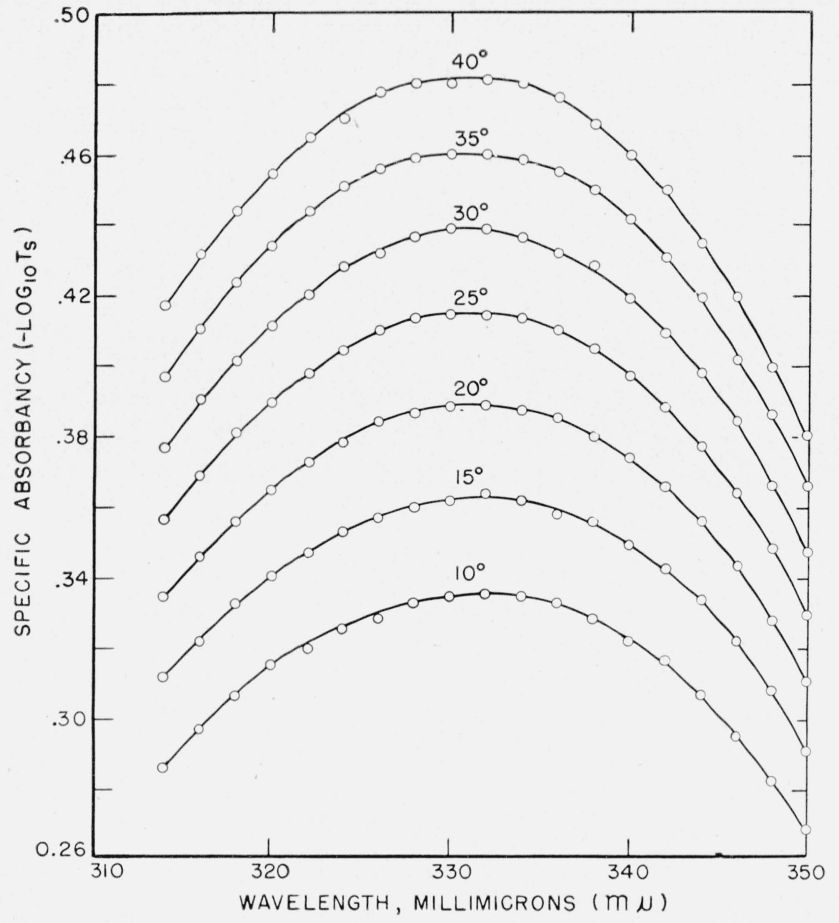

Figure 5. Effect of temperature upon the absorbancy of 4aminobenzophenone, partially dissociated in 0.0064-M hydrochloric acid ( $\mathrm{pH} 2.23)$.

\section{Other Related Thermodynamic Quan- tities}

1. Estimation of $\mathrm{p} K_{a}$ and $K_{a}$ from $10^{\circ}$ to $40^{\circ} \mathrm{C}$

True thermodynamic constants, $K_{a}$, may be calculated at each temperature studied by eq 7

$$
K_{a}=K_{c} \frac{f_{\mathrm{H}^{+}} f_{\mathrm{RNH}_{2}}}{f_{\mathrm{RNH}_{3}^{+}}}
$$

in which the activity coefficients, $f$, are expressed with the appropriate subscripts.

When $\mathrm{p} K_{c}$ is plotted as a function of ionic strength at each temperature, it is found that straight lines may be drawn through the values, giving slight slopes. Extrapolation to infinite dilution should give the $\mathrm{p} K_{a}$ values, and the activity coefficient terms may then be expressed as a linear function of ionic strength. The results are shown in figure 6 . The experimental error is at least $\pm 0.01 \mathrm{pK}$ unit, and the lines were drawn as visual estimates. $\mathrm{p} K_{a}$ was found to be $2.36,2.28,2.24,2.17,2.12,2.06$, and 2.02 for $10^{\circ}, 15^{\circ}, 20^{\circ}, 25^{\circ}, 30^{\circ}, 35^{\circ}$, and $40^{\circ} \mathrm{C}$. $K_{a}$ is then $0.0044,0.0052,0.0058,0.0068,0.0076,0.0087$, and 0.0096 in the same order.

\section{Activity Coefficient Terms}

The straight lines in figure 6 may be used to select $p K_{c}$ values at anv ionic strength between 0 and 0.03 . Corresponding $\tilde{K}_{c}$ values may then be derived. As the ratio of $K_{a}$ to $K_{c}$ is equal to the activity coefficient term $f_{\mathrm{H}^{+}} f_{\mathrm{RNH}_{2}} / f_{\mathrm{RNH}_{3}^{+}}$, this term, called $f_{R}$, may now be calculated. Some terms are shown in table 3 for a

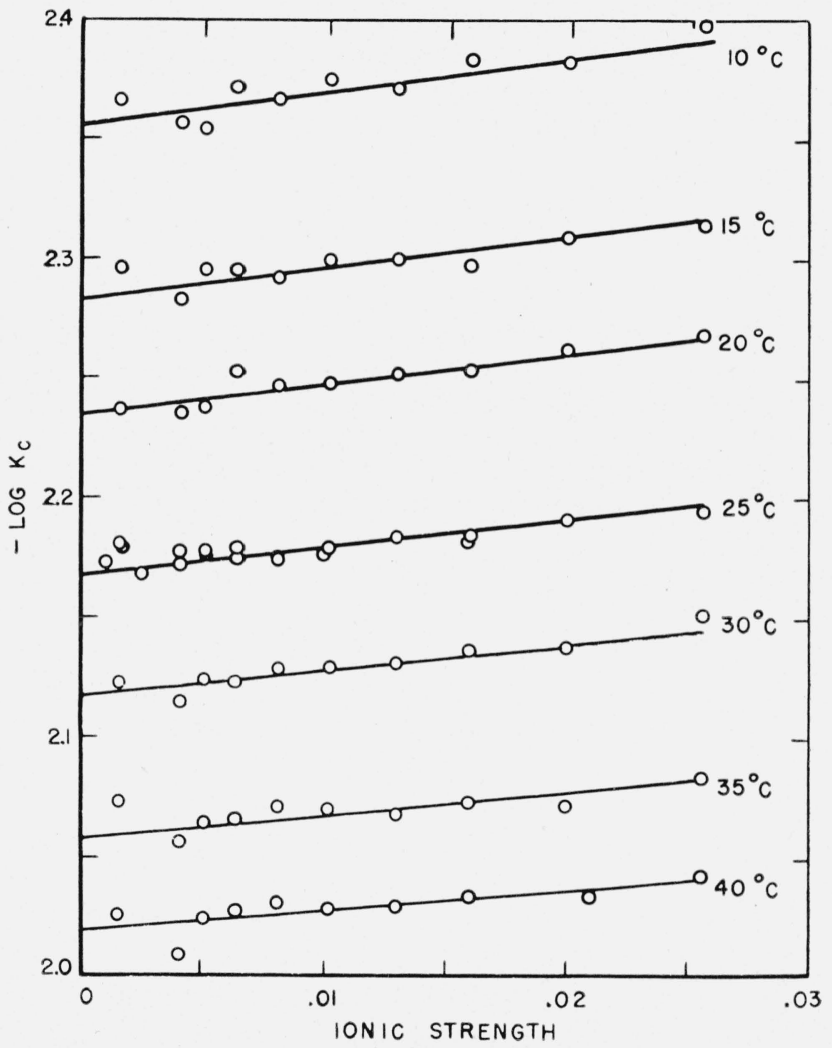

Figure 6. $\mathrm{p} K_{c}$ values of 4-aminobenzophenone at different stages in the dissociation in hydrochloric acid.

TABLE 3. Activity coefficient terms, $f_{H^{+}} f_{R N H_{2}} / f_{R N H_{3}^{+}}$or $f_{H}$, calculated for several temperatures

\begin{tabular}{|c|c|c|c|c|c|c|c|c|c|c|c|c|c|c|}
\hline \multirow{3}{*}{$\begin{array}{c}\text { Ionic } \\
\text { strength }\end{array}$} & \multicolumn{14}{|c|}{ Degrees Celsius- } \\
\hline & \multicolumn{2}{|c|}{10} & \multicolumn{2}{|c|}{15} & \multicolumn{2}{|c|}{20} & \multicolumn{2}{|c|}{25} & \multicolumn{2}{|c|}{30} & \multicolumn{2}{|c|}{35} & \multicolumn{2}{|c|}{40} \\
\hline & $K_{c} \times 10^{3}$ & $f_{R}$ & $K_{c} \times 10^{3}$ & $f_{R}$ & $K_{c} \times 10^{3}$ & $f_{R}$ & $K_{c} \times 10^{3}$ & $f_{R}$ & $K_{c} \times 10^{3}$ & $f_{R}$ & $K_{c} \times 10^{3}$ & $f_{R}$ & $K_{c} \times 10^{3}$ & $f_{R}$ \\
\hline $0.000\left(K_{a}\right)$ & 4. 41 & & 5. 21 & & 5. 83 & & 6. 81 & & 7.64 & & 8.77 & & 9. 57 & \\
\hline .005 & 4. 34 & 1. 02 & 5.14 & 1. 01 & 5. 74 & 1. 02 & 6. 71 & 1. 01 & 7. 53 & 1. 01 & 8.67 & 1. 01 & 9. 48 & 1. 01 \\
\hline .010 & 4. 27 & 1. 03 & 5. 06 & 1. 03 & 5. 66 & 1.03 & 6. 62 & 1.03 & 7. 46 & 1. 03 & 8. 57 & 1. 02 & 9. 40 & 1. 02 \\
\hline .015 & 4. 21 & 1.05 & 4. 98 & 1.04 & 5. 58 & 1.04 & 6. 53 & 1.04 & 7. 38 & 1. 04 & 8.47 & 1. 04 & 9.31 & 1.03 \\
\hline 020 & 4.15 & 1. 06 & 4. 92 & 1.06 & 5. 52 & 1.06 & 6. 46 & 1.05 & 7.30 & 1. 05 & 8.38 & 1.05 & 9. 20 & 1. 04 \\
\hline 025 & 4. 09 & 1.08 & 4.84 & 1.08 & 5. 43 & 1.07 & 6. 37 & 1.07 & 7.19 & 1. 06 & 8.30 & 1. 06 & 9.14 & 1. 05 \\
\hline .030 & 4. 02 & 1.10 & 4.78 & $\begin{array}{l}1.09 \\
\text { 1. }\end{array}$ & 5. 35 & 1. 09 & 6. 28 & 1. 09 & 7.10 & 1.08 & 8. 20 & 1. 07 & 9.06 & 1. 06 \\
\hline
\end{tabular}


few ionic strengths at the seven temperatures at which measurements were made.

There are little data in the literature on activity coefficient terms of weak bases at low ionic strengths. However, if the terms at high ionic strengths are extrapolated to lower strengths, the results of Randall and Failey [4], Harned and Robinson [5], and Harned and Mannweiler [6] obtained by electromotive-force methods and Weil and Morris [7], who used spectrophotometric methods, are in agreement with our results.

\section{Heat of Dissociation}

If one now plots the $-\log K_{a}$ values for each temperature as a function of $1 / T$, a practically straight line is obtained as shown in figure 7 . Thus the heat of dissociation can be assumed to be practically constant, and $\Delta \mathrm{H}$ may be calculated according to eq 8

$$
d \log K / d T=\Delta H / 2.3 R T^{2},
$$

in which $\Delta \mathrm{H}$ represents the molar changes of heat content for the dissociation, $R$ is the gas constant 8.3144 joules $\operatorname{deg}^{-1}$ mole $^{-1}$, and $T$ is the temperature in degrees Kelvin (degrees Celsius + 273.16). $\Delta \mathrm{H}$ is found to be 19,000 joules $\mathrm{deg}^{-1} \mathrm{~mole}^{-1}$.

\section{Basic Ionization Constant, $K_{b}$}

One may derive the basic ionization constant, $K_{b}$, from the usual relationship

$$
K_{b}=K_{w} / K_{a},
$$

in which $K_{v}$ is the activity product for water. For

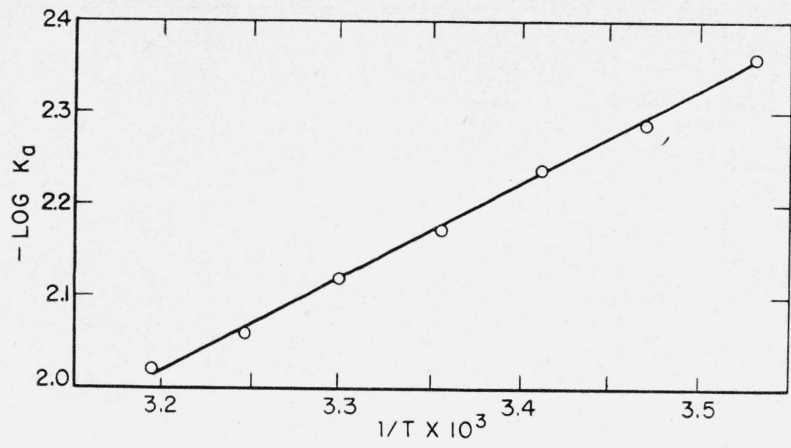

FiguRE 7. $\mathrm{p} K_{a}$ values at temperatures from $10^{\circ}$ to $40^{\circ} \mathrm{C}$ plotted as a function of $1 / T$.

example, at $25^{\circ} \mathrm{C} K_{b}$ is equal to $10^{-14} /\left(6.6 \times 10^{-3}\right)$, which yields a value of $1.6 \times 10^{-11} . \quad \mathrm{p} K_{b}$ is then approximately 11.8 .

\section{References}

[1] Elizabeth E. Sager, Harry J. Keegan, and S. F. Acree, J. Research NBS 31, 323 (1943) RP1569.

[2] Elizabeth E. Sager, Marjorie R. Schooley, and S. F. Acree, J. Research NBS 31, 197 (1943) RP1558.

[3] Elizabeth E. Sager, Marjorie R. Schooley, Alice S. Carr, and S. F. Acree, J. Research NBS 35, 521 (1945) RP1686.

4] M. Randall and C. F. Failey, Chem. Rev. 4, 27k (1927).

[5] H. H. Harned and R. A. Robinson, J. Am. Chem. Soc. 50, 3157 (1928).

[6] H. H. Harned and G. E. Mannweiler, J. Am. Chem. Soc. 57, 1873 (1935).

[7] I. Weil and J. C. Morris, J. Am. Chem. Soc. 71, 3123 (1949).

Washington, August 14, 1950

\title{
A New Method of Radioactive Standard Calibration
}

\author{
By Howard H. Seliger
}

\begin{abstract}
By proper arrangement of experimental observations and statistical analysis it has been possible to make Geiger-counter measurements of different activity samples independent of intermittent disturbing effects. The results of 5,328 individual measurements, involving more than $1.4 \times 10^{8}$ counts made by using a Latin square arrangement, are shown to have an error distribution identical with that expected from the statistical nature of the disintegration process. A completely worked out example of a calibration procedure is given, in which it has been possible to achieve a higher degree of accuracy in only 30 percent of the original counting time.
\end{abstract}

\section{Introduction}

Anyone who has had occasion to make Geigercounter measurements on radioactive isotopes has found at times that his results were not self-consistent; or more precisely, that readings taken at time $A$ could not be duplicated within the expected Poisson deviation at time $B$. Sometimes upon further investigation it was found that these variations were due to fluctuations in the electronic voltage supply, slight changes in sensitivity of the Geiger counter itself, or other transient effects. Most often, if it were not too time-consuming, the original data were discarded and the measurements repeated, this time with the fingers crossed. In this paper a procedure for arranging and analyzing a series of measurements is described that eliminates intermittent disturbing effects and that permits a determination to be made as to whether the variance of the set of readings is a reasonable one to expect on the basis of a Poisson distribution of counts. The end result is that all readings of a set are treated 